\title{
Den goda handledningen - om relation, stöttning och lärande
}

\author{
Jörgen Lundälv \\ Institutionen för socialt arbete, Göteborgs universitet
}

\begin{abstract}
Magnusson, Jenny \& Zackariasson, Maria (202I). Handledning i praktiken - om studenters självständighet och akademiska litteracitet. Lund: Studentlitteratur, 224 sidor.
\end{abstract}

Att det skrivs böcker om handledning och uppsatsskrivande är inte något nytt. Det finns en rad böcker som genom åren har behandlat området och lyft fram olika utmaningar. Därför kan man se boken "Handledning i praktiken" som ytterligare en bok som kan vara ett verktyg för uppsatshandledare i den högre utbildningen. För universitetslärare är boken en öppning till att ta del av andra handledares erfarenheter och förhållningssätt och man kan känna sig både ensam och ibland vilsen i sin roll som ny men även som senior handledare. För det är nämligen viktigt att betänka att en handledare ständigt lär sig av möten och processer med studenter, andra handledare och examinatorer. Som uppsatshandledare med över tjugo års erfarenhet av handledning och undervisning i vetenskaplig metod och andra ämnen känner jag läslust och vill öppna boken med titeln "Handledning i praktiken - om studenters självständighet och akademiska litteracitet". Boken är skriven av Jenny Magnusson, docent i svenska vid Södertörns högskola och Maria Zackariasson, professor i etnologi vid samma högskola.

Att handledning av självständiga arbeten inom den högre utbildningen är utbredd går inte att ta miste om. Redan i bokens inledning beskriver författarna att det skrivs över Ioo ooo självständiga arbeten (uppsatser) årligen. Men vad händer under dessa processer där handledningen är en viktig del? Hur gick resan och vilka lärdomar har dragits av handledningen i praktiken? Den här boken beskriver flera viktiga och intressanta resultat från ett forskningsprojekt där både handledare och studenter medverkat med sina kunskaper och erfarenheter. Genom att ha samlat in ett stort material bestående av fokusgruppintervjuer, inspelade handledningsmöten, studentenkät och dokument (kursplaner för självständiga arbeten) har bokens författare ett värdefullt material att presentera.

Boken består av åtta kapitel där läsaren får ta del av såväl empiriska perspektiv som teoretiska perspektiv på vad handledning kan vara. Bokens andra kapitel beskriver olika teoretiska perspektiv på handledning. Här redogör författarna för att handledningen kan vara både individuell, social och kollegial praktik. Studenterna får input från lärare och handledning, också från sina studiekamrater under uppsatsprocessen. Detta är inga nya perspektiv utan författarna hänvisar till tidigare forskning inom området. I tredje kapitlet introduceras två begrepp; självständighet och kritiskt tänkande. Begreppen förklaras och sätts i sina sammanhang men det hade varit bättre och mer överskådligt i boken om det till exempel hade funnits en ordlista eller begreppsförteckning. Då hade det varit enkelt att finna definitionerna av de begrepp som är

*Författarkontakt: Jorgen.Lundalv@socwork.gu.se

Artiklar och reflektioner är kollegialt granskade. Övriga bidragstyper granskas av redaktionen. Se https://hogreutbildning.se ISSN 2000-7558

(C2021 Jörgen Lundälv. This is an Open Access article distributed under the terms of the Creative Commons Attribution 4.0 International License (https://creativecommons.org/licenses/BY/4.0/), allowing third parties to share their work (copy, distribute, transmit) and to adapt it, under the condition that the authors are given credit, that the work is not used for commercial purposes, and that in the event of reuse or distribution, the terms of this license are made clear.

Citation: Lundälv, J. (2021). "Den goda handledningen - om relation, stöttning och lärande», Högre utbildning, 11(2), 84-86. https://doi.org/ $10.23865 /$ hu.v11.3486 
centrala. I kapitel fyra beskrivs relationen mellan handledare och student. Här hade författarna på ett tydligare sätt kunnat utgå från begreppen tillit och förtroende, två begrepp som kan sägas vara bärande för relationen. Jag saknar definitioner av dessa viktiga begrepp, något som hade kunnat stärka avsnittet. Det är bra att författarna beskriver betydelsen av professionalitet och likaså det personliga och privata, men utgångspunkten för att en relation ska kunna etableras och utvecklas är att det finns förtroende och tillit.

Läsaren får både bekanta sig med och får en fördjupning av hur det kan vara att bygga relationer med studenter samtidigt som författarna berättar och ger exempel på känslomässiga aspekter av handledningen såsom olika reaktioner, osäkerhet och oro. Till detta får läsaren också ta del av vilka olika stöttningsverktyg som finns i handledningssamtalet där både krav, uppmaningar och beröm lyfts fram som viktiga delar. Boken avslutas med både råd och reflektioner om hur viktigt det är att reflektera, diskutera och kommunicera erfarenheter. I slutet finns också en referenslista på litteratur som behandlar handledning i den högre utbildningen.

Ett teoretiskt fält som introduceras i början av boken är academic literacies (akademisk litteracitet). Författarna skriver: "inkluderar alla de aktiviteter som omgärdar det akademiska skrivandet, vilket innebär att det också är relaterat till sociala och institutionella praktiker, maktrelationer, hierarkier och identiteter" (s. I6). Efter genomläsning av boken upplever jag som läsare och recensent flera stärkande perspektiv och tankar. Boken har givit mig som universitetslärare och handledare sedan många år tillbaka något att tänka på. Författarna har med innehållet och språket i boken berört mig på flera vis. Att vara handledare kan vara en svår roll. I boken presenteras citat från det insamlade materialet; samtal mellan studenter och handledare. Detta gör att bokens innehåll blir levande och mycket nära. Här återfinns olika inslag i handledarrelationen, frågorna och ibland ovissheten men även känslorna. Precis som framgår i boken handlar det om att kunna vara både positiv och konstruktiv i såväl läsningen som vid själva handledningstillfället. Även om handledaren har haft en god relation med studenterna och att uppsatsen har blivit färdig i tid så kan det uppstå olustiga och förvånande scenarier för alla inblandade.

Helt plötsligt kommer examinatorn från ett helt annat rum och gör helt andra bedömningar av uppsatsen och underkänner densamma. De stora och påtagliga skillnaderna i bedömningen av uppsatsen som nu uppstått mellan handledare och examinator kan leda fram till stor besvikelse och misstro hos studenterna mot systemet. I boken skriver författarna följande: "Ur ett akademiskt litteracitetsperspektiv är det inte förvånande, utan snarast förväntat, att handledare och examinatorer kan göra olika bedömningar av samma text, framför allt om de kommer från olika ämnesdiscipliner. En grundläggande tanke där är ju just att akademiskt skrivande, och de förväntningar och bedömningar som är knutna till det, skiljer sig åt mellan olika lokala akademiska kontexter. Samtidigt är det en aspekt av uppsatsarbetet som kan vara svår för både handledare och studenter att förhålla sig till” (s. 173). Det är intressant att läsa exemplen i boken och författarnas resonemang om hur exempelvis en examinators bedömning av en uppsats också får en direkt inverkan på handledarens praktik. Av detta följer att en del handledare undviker att uttala sig om värdeomdöme om en uppsats innan den lämnats in för examination. Det är viktigt att en examinator anger tydliga motiveringar till sin bedömning av uppsatsen och dess betyg. Eftersom det är en lärandeprocess för studenterna så måste ju de också få en chans att göra revideringar och även förstå på vilket sätt som något i en text kan förbättras. Det finns flera styrkor i boken. Jenny Magnusson och Maria Zackariasson lämnar inte läsaren utan att ge råd och alternativ till hur situationer kan förstås och kanske till och med lösas. Detta är något som känns väldigt bra för en läsare genom hela boken. En styrka är att författarna tar hand om läsaren och berör samtidigt som läsaren också kan stanna upp och självständigt reflektera utifrån innehållet. 


\section{Jörgen Lundälv}

Att vara handledare och examinator är två olika roller. I sin roll kan universitetsläraren känna sig ensam trots att man är verksam på en institution bland kollegor. För en erfaren handledare eller examinator kan det finnas stora förväntningar. När handledare och examinator bedömer uppsatsen på olika vis kan det handla om mer eller mindre stora diskrepanser. Författarnas råd här är att man till exempel skulle kunna använda som redskap det faktum att examinatorer också har haft erfarenhet som handledare av andra studenter. Genom att universitetsläraren har erfarenhet av båda rollerna som examinator och handledare, så skulle han eller hon kunna delta aktivt i ett kollegialt samtal i såväl handledarkollegier som examinationsmöten för att kunna få ett utbyte och gemensam förståelse.

Jenny Magnusson och Maria Zackariasson beskriver olika situationer och dilemman som kan uppstå i handledningsrelationen med studenter. En annan styrka i boken är att de lyfter fram sådant som kan vara svårt att hantera både som ny handledare och när du varit handledare under några år. Hur hanterar du till exempel situationen om relationen till studenterna blir för personlig eller privat? Att vara medveten om den beroendesituation som studenterna befinner sig i är mycket viktigt. En del studenter begär att få byta handledare eller gör tillfälliga studieuppehåll. Många olika händelser kan inträffa under en uppsatsprocess. Många studenter vill bli klara i tid med sin uppsats. De vill hålla tiden och uppsatsskrivandets våndor kan innebära stor stress och press under lärandeprocessen. Som handledare är det också viktigt att kunna diskutera och utbyta erfarenheter med kollegor. Inte minst är det viktigt att kunna få stöd och råd i olika situationer. Och det är just sådana samtal som förs fram i den här boken. Därför är den fylld med lösningsfokuserat arbete och har kreativa och konstruktiva toner.

Efter att ha läst denna bok saknar jag författarnas framtidsblickar och förslag på vidare forskning. Författarna har lång erfarenhet av forskning och det hade varit intressant om de hade lämnat frågor angelägna för vidare forskning. Förvisso tar bokens sista kapitel upp råd och reflektioner men här skulle författarna också kunnat ha lyft fram fler frågor. Detta hade varit intressant och välbehövligt inte minst för hur den högskolepedagogiska forskningen kan utvecklas och stärkas.

Avslutningsvis kan sägas att boken är ett tillskott till annan handledningslitteratur eftersom den innehåller både röster från handledare och studenter. Jag vill varmt rekommendera boken för läsning. 